\title{
Registration Coordinator
}

National Cancer Institute

\section{Source}

National Cancer Institute. Registration Coordinator. NCI Thesaurus. Code C51861.

A person that is responsible for the integration and collation of subject information and

participation throughout the duration of the clinical trial, and subsequent follow-up. 